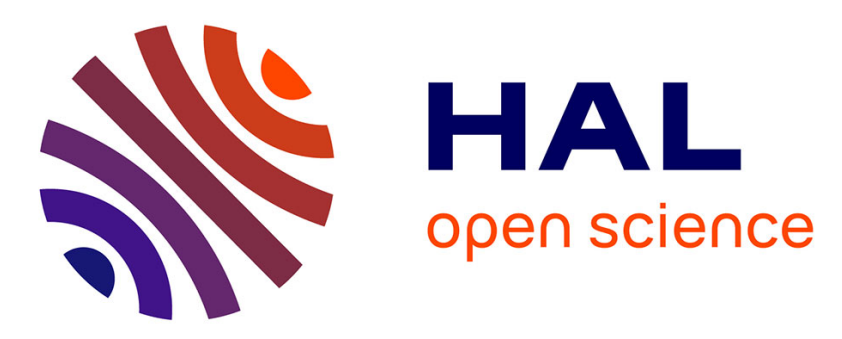

\title{
Honeybee biomarkers as promising tools to monitor environmental quality
}

\author{
A. Badiou-Bénéteau, Aurore Benneveau, F. Géret, Hélène Delatte, Nathalie \\ Becker, J. L. Brunet, Bernard Reynaud, L. Belzunces
}

\section{- To cite this version:}

A. Badiou-Bénéteau, Aurore Benneveau, F. Géret, Hélène Delatte, Nathalie Becker, et al.. Honeybee biomarkers as promising tools to monitor environmental quality. Environment International, 2013, 60, pp.31-41. 10.1016/j.envint.2013.07.002 . hal-01456745

\section{HAL Id: hal-01456745 \\ https: / hal.univ-reunion.fr/hal-01456745}

Submitted on 29 May 2020

HAL is a multi-disciplinary open access archive for the deposit and dissemination of scientific research documents, whether they are published or not. The documents may come from teaching and research institutions in France or abroad, or from public or private research centers.
L'archive ouverte pluridisciplinaire HAL, est destinée au dépôt et à la diffusion de documents scientifiques de niveau recherche, publiés ou non, émanant des établissements d'enseignement et de recherche français ou étrangers, des laboratoires publics ou privés. 


\title{
Honeybee biomarkers as promising tools to monitor environmental quality
}

\author{
A. Badiou-Bénéteau a,*, A. Benneveau ${ }^{\text {b }}$, F. Géret ${ }^{\text {c }}$, H. Delatte ${ }^{\text {d }}$, N. Becker ${ }^{\text {e }}$, J.L. Brunet ${ }^{\text {a }}$, \\ B. Reynaud ${ }^{\mathrm{d}}$, L.P. Belzunces ${ }^{\mathrm{a}, *}$ \\ a INRA, UR 406 Abeilles E Environnement, Laboratoire de Toxicologie Environnementale, 84914 Avignon Cedex 9, France \\ b CIRAD, UMR PVBMT, F-97410 Saint-Pierre, La Réunion, France \\ c Université d'Albi, UMR CNRS 5602 Centre Universitaire Jean-François Champollion, Laboratoire GEODE, 81012 Albi cedex 9, France \\ d CIRAD, UPR HORTSYS, F-97455 Saint-Pierre, La Réunion, France \\ e MNHN, UMR CNRS 7205, Origine, Structure et Evolution de la Biodiversité, 75231 Paris, France
}

\begin{abstract}
A B S T R A C T
The aim of this study was to distinguish the impacts of two different anthropogenic conditions using the honeybee Apis mellifera as a bioindicator associated with a battery of biomarkers previously validated in the laboratory. Both the urban (RAV, Ravine des Cabris) and semi-natural (CIL, Cilaos) sites in La Reunion Island were compared in order to assess the impacts of two types of local pollution using the discriminating potential of biomarkers. Hives were placed at the CIL and RAV sites and honeybees were collected from each hive every three months over one year. Honeybee responses were evaluated with respect to several biochemical biomarkers: glutathione-S-transferase (GST), acetylcholinesterase (AChE), alkaline phosphatase (ALP) and metallothioneins (MT). The results showed a significant difference between the localities in terms of GST, AChE and ALP activities, as regarding midgut MT tissue levels. Compared to the CIL site, ALP and MT tissue levels were higher at the RAV site, although AChE activity was lower. GST displayed more contrasted effects. These results strongly suggest that the honeybees based in the more anthropized area were subjected to sublethal stress involving both oxidative stress and detoxification processes with the occurrence of neurotoxic pollutants, amongst which metals were good candidates. A classification tree enabled defining a decision procedure to distinguish the sampling locations and enabled excellent classification accuracy (89\%) for the data set. This field study constitutes a strong support in favour of the in situ assessment of environmental quality using honeybee biomarkers and validates the possibility of performing further ecotoxicological studies using honeybee biomarkers.
\end{abstract}

\section{Introduction}

La Réunion Island benefits from considerable plant diversity and part of the island was granted the status of a UNESCO World Heritage Site in 2010. The island displays a high degree of endemism and rare terrestrial biodiversity. In view of the important and often irreversible impacts of human activity on this ecosystem, there is an increasing need to develop tools to monitor the impacts of pollution. Bioindicators represent good witnesses of environmental health and their presence, or the structure of their populations, could be considered as highly informative. However, characterization of the physiological integrity and functionality of individuals requires tools to act as biomarkers of exposure to environmental stressors. Biomarkers can be defined as observable or measurable modifications at the molecular, cellular, physiological or behavioural levels which reveal the exposure of an

* Corresponding authors at: INRA, Laboratoire de Toxicologie Environnementale, UR 406 Abeilles E' Environnement, 84914 Avignon Cedex 9, France. Tel.: + 3343272 2604; fax: + 33 432722602.

E-mail addresses: alexandra.badiou@avignon.inra.fr (A. Badiou-Bénéteau), luc.belzunces@avignon.inra.fr (L.P. Belzunces). organism to xenobiotics (Lagadic et al., 1997). Biomonitoring programmes are usually based on studying a set of biomarkers in sentinel species of interest (Aguilera et al., 2012; Damiens et al., 2004; Lionetto et al., 2003; Stanic et al., 2006). In the terrestrial environment, the honeybee is a particularly pertinent model for the development of biomarkers in order to assess environmental contamination (Leita et al., 2004; Saifutdinova and Shangaraeva, 1997). Honeybees can constitute reliable indicators of environmental quality because their intense foraging activity brings them into contact with a large number of pollutants within a radius that generally ranges from 1.5 to $3 \mathrm{~km}$ around the hive, depending on food abundance (Chauzat et al., 2009). A decline in honeybee populations is currently being seen in many parts of the world, resulting in an active strategy for the monitoring and diagnosis of population health (Nguyen et al., 2009). The honeybee is therefore a species of particular interest in terrestrial ecotoxicology because its physiology, behaviour and ecology have been the subject of extensive study (Alaux et al., 2010; Decourtye et al., 2004; Henry et al., 2012).

The responses of some biochemical parameters, such as alkaline phosphatase, acetylcholinesterase and glutathione-S-transferase, have 
Version définitive du manuscrit publiée dans / Final version of the manuscript published in :

Environment International (2013) Vol. 60, p. 31- 41, DOI: 10.1016/ị.envint.2013.07.002

Journal homepage: www.elsevier.com/locate/envint

Table 1

General characteristics of the selected sites.

\begin{tabular}{lll}
\hline & CILAOS (CIL) & RAVINE DES CABRIS (RAV) \\
\hline GPS coordinates & E55 $27^{\prime} 19.9^{\prime \prime}$ & E55 $28^{\prime} 36.3^{\prime \prime}$ \\
& ${\mathrm{S} 21^{\circ} 15^{\prime} 45^{\prime \prime}}^{\prime}$ & $\mathrm{S}^{\circ} 17^{\prime} 12.7^{\prime \prime}$ \\
Anthropogenic pressure & Semi-natural & Dense urban \\
Altitude (m) & 238 & 250 \\
Sampling period & May 2009 to May 2010 & May 2009 to May 2010 \\
\hline
\end{tabular}

been characterized in laboratory studies after the exposure of honeybees to various chemicals (Bounias et al., 1985, 1996; Stefanidou et al., 1996). Their response profiles to chemicals mean that honeybees can be considered as promising tools for use in environmental biomonitoring programmes. However, no in situ validations have been performed to date. During previous studies, we validated the responses to a battery of metabolic and neural biomarkers of Apis mellifera honeybees after their exposure to chemicals under laboratory conditions (Badiou-Bénéteau et al., 2012). The purpose of the present study was therefore to validate honeybee biomarkers under field conditions. Urban (RAV, Ravine des Cabris) and semi-natural (CIL, Cilaos) locations in La Reunion Island were compared in order to evaluate the impacts of two types of local pollution using the discriminating potential of biomarkers. The biomarkers chosen for this study included non-specific and specific biomarkers of pollutant toxicity. We focused this study on metabolic biomarkers such as alkaline phosphatase (ALP) and glutathione-S-transferase (GST), a neural biomarker, acetylcholinesterase (AChE), and metal biomarkers such as metallothioneins (MT). Metals and pesticides were also quantified in the honeybees in order to determine the pollutants to which they had been exposed.

\section{Materials and methods}

\subsection{Experimental design}

The study sites were located in the south-western part of La Réunion Island and displayed contrasting degrees of anthropisation: a weakly anthropised rural site, CIL (Cilaos, E55 $-27^{\prime}-19.9^{\prime \prime} ;$ S21 ${ }^{\circ}-15^{\prime}-45^{\prime \prime}$ ) and a strongly anthropised urban site, RAV (Ravine des Cabris, E55 ${ }^{\circ}-28^{\prime}$ 36.3"; S21 ${ }^{\circ}-17^{\prime}-12.7^{\prime \prime}$ ) (Table 1 and Fig. 1). The rural site (CIL) was relatively landlocked between the feet of the Cilaos mountain (the hives being located close to the mountain) and the Cilaos ravine, inducing foraging activity where no industrial contamination could be detected. This site was chosen as the relative reference. The urban site (RAV) was located in the suburbs of Saint Pierre, separated from the CIL site by the cirque de Cilaos. To reduce any variations due to geographical factors (microclimates prevailing on La Réunion Island), the sampling sites were situated within the same ecoregion, separated by a distance of $3.7 \mathrm{~km}$. It was assumed the foraging zones of the bees were relatively independent and restricted to their respective sites because (i) food resources were deemed to be sufficient in the area surrounding the hives, based on the amount of honey produced, and (ii) a broad and deep ravine separates the sites, dissuading the bees from crossing it. Six A. mellifera honeybee colonies were placed at the CIL and RAV locations (three colonies per site) and samples were collected every three months over a 1-year period. Foraging A. mellifera honeybees were captured at the hive entrance. Sampling for analysis was carried out simultaneously in the colonies of both sites, with approximately 2000 honeybees being collected each time (around $200 \mathrm{~g}$ of honeybees) from each hive.

\subsection{Determination of honeybee races}

In the subtropical island of La Réunion, the dominant race of honeybee is A. mellifera unicolor (Ruttner, 1975, 1988; Schneider, 1989), although several European races of A. mellifera (carnica, ligustica, mellifera) are known to have been introduced in the past (Schneider, 1989). It was therefore necessary to verify the races of the honeybee populations used during this study, and the homogeneity of our samples. Two workers per colony were taken from the samples collected for the biomarker study, and preserved in alcohol before extraction of their DNA. The mtDNA region including the tRNAleu gene, the COICOII intergenic region and the $5^{\prime}$ end of the COII subunit gene were PCR-amplified according to a protocol detailed by Garnery et al. (1993). A fraction of the PCR product was run on 1\% agarose gel for total size determination and the remaining product was restricted

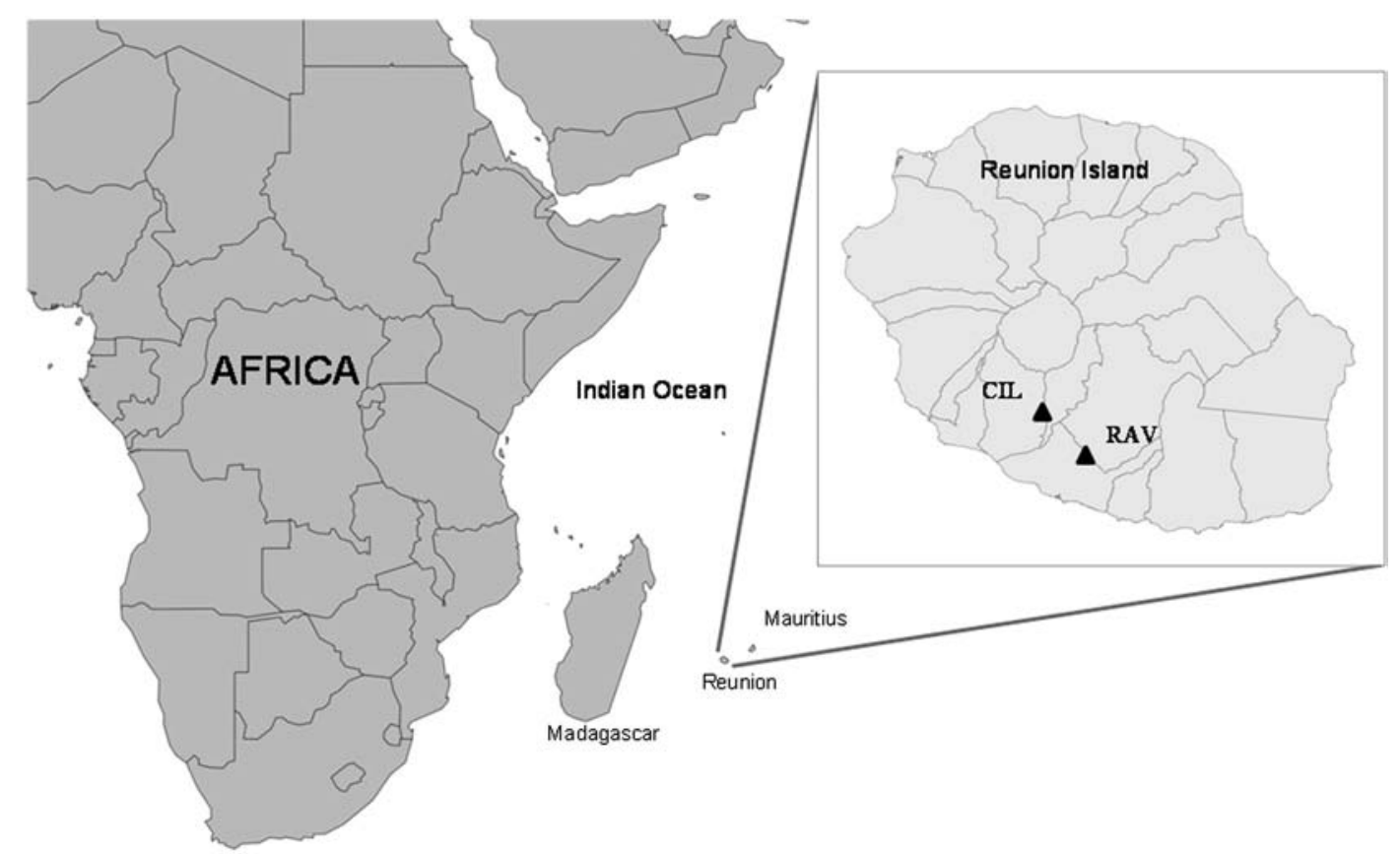

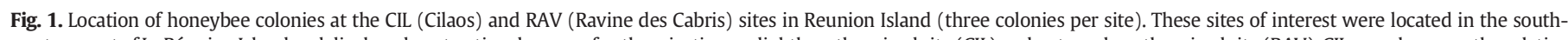

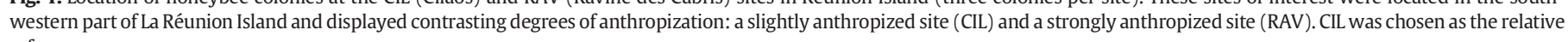
reference. 
Environment International (2013) Vol. 60, p. 31- 41, DOI: 10.1016/j.envint.2013.07.002

\section{Journal homepage: www.elsevier.com/locate/envint}

with DraI prior to electrophoresis, according to the detailed protocol used by Franck et al. (2001). Restriction profiles were read and the sizes compared to those published by Franck et al. (2001) for the south-western Indian Ocean region.

\subsection{Enzyme extractions}

To prevent any animal suffering, the honeybees were anaesthetised with carbon dioxide and their tissues sampled immediately. The head was removed first, followed by the midgut. All tissues and honeybees were stored at $-80^{\circ} \mathrm{C}$ until analysis. AChE was extracted from the honeybee head and GST and ALP were extracted from the midgut. Each tissue extract was prepared by homogenising five heads or midguts in an appropriate buffer to make a 10\% (w/v) extract. For enzyme quantification, twelve extracts were performed and assayed in triplicate. Two homogenisation media were used, depending on the type of enzyme to be studied: $10 \mathrm{mM} \mathrm{NaCl}$ and $40 \mathrm{mM}$ sodium phosphate, $\mathrm{pH}$ 7.4, for soluble enzymes (GST and ALP), and 1\% Triton X-100, $10 \mathrm{mM} \mathrm{NaCl}$ and $40 \mathrm{mM}$ sodium phosphate, pH 7.4, for the membrane enzyme (AChE). The homogenization media contained a mixture of $5 \mu \mathrm{g} \cdot \mathrm{mL}^{-1}$ of antipain, leupeptin and pepstatin A, 25 units. $\mathrm{mL}^{-1}$ aprotinin and $0.1 \mathrm{mg} \cdot \mathrm{mL}^{-1}$ soybean trypsin as protease inhibitors. Tissue homogenisation was performed using a high speed TissueLyser II homogeniser (Qiagen ${ }^{\circledR}$ ) for three periods of $30 \mathrm{~s}$ at 30 -second intervals, and the extracts were then centrifuged at $4{ }^{\circ} \mathrm{C}$ for $20 \mathrm{~min}$ at $15,000 \mathrm{~g}$. The resulting supernatants were split and frozen at $-20{ }^{\circ} \mathrm{C}$ for subsequent analysis.

\subsection{Enzyme assays}

Biochemical analyses were performed using a Bioblock dual-beam microplate UV-Visible spectrophotometer. Enzyme assays were performed at $25{ }^{\circ} \mathrm{C}$ except for GST, which was assayed at $37{ }^{\circ} \mathrm{C}$ according to the method described by Roméo et al. (2003) with minor modifications. GST was measured at $340 \mathrm{~nm}$ in a medium containing $1 \mathrm{mM}$ EDTA, $2.5 \mathrm{mM}$ GSH (reduced glutathione), $1 \mathrm{mM}$ 1-chloro-2,4-dinitrobenzene as the substrate and $40 \mathrm{mM}$ sodium phosphate $\mathrm{pH}$ 7.4. Protein concentrations were estimated using the method described by Bradford (1976), with bovine serum albumin as the standard. AChE activity was measured at $412 \mathrm{~nm}$ according to the technique described by Ellman et al. (1961) with modifications from Belzunces et al. (1988). ALP was monitored at $410 \mathrm{~nm}$ in a medium containing $20 \mu \mathrm{M} \mathrm{MgCl}$, $2 \mathrm{mM}$ p-nitrophenyl phosphate as the substrate and $100 \mathrm{mM}$ Tris-HCl pH 8.5 (Bounias et al., 1996). For AChE and ALP, one unit of enzyme activity was defined as the quantity of enzyme that hydrolysed $1 \mu \mathrm{mol}$ of substrate per min, under these assay conditions. For GST, one unit of activity corresponded to the quantity of enzyme conjugating $1 \mu \mathrm{mol}$ of GSH per min.

\subsection{Analysis of metals}

Twenty-one metals were analysed in the head and midgut of the honeybees (Table 2). The metals were analysed using Inductively Coupled Plasma/Mass Spectrometry (ICP-MS) according to the NF EN ISO 17294 standard. A quantity of $0.1 \mathrm{~g}$ of bees was put in a reactor with a mixture containing $38 \%$ nitric acid, $10 \%$ hydrogen peroxide and $4 \% \mathrm{HCl}$. The reactors were then placed in a Multiwave 3000 microwave oven (Anton Paar) and subjected to the following treatment cycle: a 0 $600 \mathrm{~W}$ gradient for $15 \mathrm{~min}$, a plateau at $600 \mathrm{~W}$ for $20 \mathrm{~min}$, and a $600-$ $0 \mathrm{~W}$ gradient for $15 \mathrm{~min}$.

\subsection{Analysis of metallothioneins}

The heads and midguts were separated from the honeybees, weight and homogenised in 10 volumes of buffer ( $10 \mathrm{mM} \beta$-mercaptoethanol, protease inhibitors (SigmaFAST Protease Inhibitor, SIGMA) and $20 \mathrm{mM}$ Tris- $\mathrm{HCl} \mathrm{pH} \mathrm{7.4).} \mathrm{The} \mathrm{homogenates} \mathrm{were} \mathrm{centrifuged} \mathrm{at} 4{ }^{\circ} \mathrm{C}$ for $30 \mathrm{~min}$ at $30,000 \mathrm{~g}$. Supernatants were subjected to heat-denaturation for
$15 \mathrm{~min}$ at $75^{\circ} \mathrm{C}$ and centrifuged for $15 \mathrm{~min}$ at $10,000 \mathrm{~g}$. The newly obtained supernatants were frozen at $-80{ }^{\circ} \mathrm{C}$ until metallothionein (MT) quantification. MT levels in heat-denatured supernatants were estimated by differential pulse polarography (DPP) (Thompson and Cosson, 1984). The amount of MT in the supernatants was quantified using the standard addition method, with rabbit liver metallothioneins (COGER, ALX-202-072-MO) as the reference material. MT concentrations were expressed as $\mu$ g.mg ${ }^{-1}$ of proteins.

\subsection{Analysis of pesticides}

Sixty-four pesticides were screened using a multi-residue analysis based on a modified QuEChERS method, followed by gas chromatography coupled with Time of Flight mass spectrometry (GC-ToF) or liquid chromatography coupled with tandem mass spectrometry (LC-MS/MS), depending on their properties. This analytical approach had been developed specifically by Wiest et al. (2011) to detect pesticides in honeybees. Briefly, the QuEChERS method combines a salting-out liquid-liquid extraction with acetonitrile $(\mathrm{ACN})$ and a dispersiveSPE clean up. Five grammes of honeybees were extracted in ACN/ water/hexane and citrate QuEChERS salts (10/3/3) and analysed using LS-MS/MS or GC-ToF. Samples were prepared in $90 / 10$ of the mobile phase $(0.3 \mathrm{mM}$ ammonium formate and $0.05 \%$ formic acid/ $\mathrm{ACN}$ ) and their analytical volume was $10 \mu \mathrm{l}$. GC-ToF analysis was performed with a 6890 Agilent gas chromatograph (Agilent Technologies, Avondale, USA) coupled with a Time of Flight (ToF) mass spectrometer GCT Premier from Waters. Samples $(1 \mu \mathrm{L})$ were injected into a $30 \mathrm{~m}$ chromatographic column with helium as the carrier gas. The initial temperature of $80^{\circ} \mathrm{C}$ was increased to $320^{\circ} \mathrm{C}$. Using a combination of LC-MS/MS and GC-ToF, the active substances analysed were: Aldrin, Amitraz, Benalaxyl, Bifenthrin, Bitertanol, Bromopropylate, Bupirimate, Buprofenzin, Piperonyl butoxide, Cadusaphos, Carbaryl, Carbofuran, Chlorpyrifos, Chlorpyrifos methyl, Clothianidin, Coumaphos, Cyfluthrin, Cypermethrin, Cyproconazole, DDT, Deltamethrin, Diazinon, Dichloran, Dichlorvos, Dicofol, META, Dieldrin, Dimethoate, Endosulfan alpha, Endosulfan beta, Endosulfan sulphate, Esfenvalerate, Ethoprofos, Fenarimol, Fenitrothion, Flusilazole, HCB, Imidacloprid, Lindane, Malathion, Metamidiphos, Methoxychlor, Myclobutanil, Paclobutrazide, Parathion, Penconazole, Permethrin, Phenthoate, Phosalone, Phosmet, Prochloraz, Propargite, Propiconazole, Pyriproxyfen, tau-Fluvalinate, Tebuconazole, Tetradifon, Tolclofos methyl, Thiamethoxam, Triphenylphosphate and Vinclozoline. The limit of detection (LOD) was around $1 \mathrm{ng} / \mathrm{g}$ and the limit of quantification (LOQ) around $10 \mathrm{ng} / \mathrm{g}$.

\subsection{Statistical analysis}

Statistical analyses were performed with $\mathrm{R}$ software on untransformed data. Firstly, in order to compare the mean levels of metals found at the RAV and CIL sites, Student's t-Test was used. Two-way ANOVA was then used to test the site and season effects and the interaction of both effects on the activity of each biomarker. The construction of a classification tree was performed using the "Tree" package, grown by binary recursive partitioning. At each stage, the split that produced the most homogeneous classes was chosen and the process was then repeated. Splitting continued until the terminal nodes were too small or too few to be split. The leave-one-out method was used to choose the optimal leaf number by minimising the misclassification rate, and to calculate the real error rates.

\section{Results}

\subsection{Analysis of metals and pesticides in the honeybees}

The levels of different metals were analysed in bees from each site (Table 2). A test of the equality of means between bees from the CIL and RAV sites was performed for each metal. The profiles of these 
Table 2

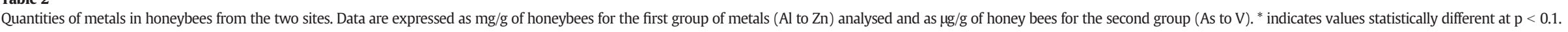

\begin{tabular}{|c|c|c|c|c|c|c|c|c|c|}
\hline & \multicolumn{3}{|l|}{ May } & \multicolumn{3}{|l|}{ August } & \multicolumn{3}{|l|}{ November } \\
\hline & CIL & RAV & $\mathrm{p}$ & CIL & RAV & $\mathrm{p}$ & CIL & RAV & $\mathrm{p}$ \\
\hline $\mathrm{Al}$ & $114.69 \pm 16.7$ & $110.07 \pm 31.33$ & 0.757 & $79.61 \pm 11.18$ & $116.74 \pm 56.44$ & 0.17 & $128.83 \pm 32.59$ & $460.41 \pm 435.99$ & $0.091^{*}$ \\
\hline B & $174.64 \pm 35.21$ & $210.76 \pm 40.47$ & 0.13 & $191.64 \pm 24.91$ & $182.72 \pm 31.77$ & 0.6 & $181.72 \pm 17.98$ & $127.64 \pm 53.77$ & $0.039^{*}$ \\
\hline $\mathrm{Ca}$ & $9889.96 \pm 976.43$ & $10,269.35 \pm 830.2$ & 0.485 & $10,114.31 \pm 910.15$ & $10,544.76 \pm 689.85$ & 0.378 & $10,103.37 \pm 959.13$ & $11,622.29 \pm 2886.6$ & 0.229 \\
\hline $\mathrm{Cu}$ & $226.59 \pm 18.98$ & $\begin{aligned} 226.81 & \pm 5.1 \\
118078 & +16906\end{aligned}$ & 0.979 & $239.96 \pm 16.86$ & $228.62 \pm 8.89$ & 0.176 & $225.56 \pm 20.51$ & $197.51 \pm 18.96$ & $0.026^{*}$ \\
\hline $\mathrm{Fe}$ & $1201.67 \pm 157.86$ & $1180.78 \pm 169.06$ & 0.829 & $1170.39 \pm 71.34$ & $1209.14 \pm 26$ & 0.256 & $1151.76 \pm 92.56$ & $1949.46 \pm 977.76$ & $0.074^{*}$ \\
\hline $\mathrm{K}$ & $17,779.13 \pm 1134.41$ & $17,587.04 \pm 1376.62$ & 0.797 & $17,192.42 \pm 656.92$ & $17,755.31 \pm 1790.33$ & 0.496 & $16,875.86 \pm 1500.63$ & $14,600.08 \pm 1999.7$ & $0.043^{*}$ \\
\hline Mg & $9288.43 \pm 641.23$ & $8926.74 \pm 368.65$ & 0.259 & $9126.76 \pm 239.97$ & $9170.86 \pm 223.93$ & 0.749 & $9052.62 \pm 705.56$ & $8781.59 \pm 1124.22$ & 0.621 \\
\hline $\mathrm{Mn}$ & $1239.51 \pm 293.53$ & $1398.43 \pm 205.9$ & 0.303 & $1501.84 \pm 157.39$ & $1452.23 \pm 306.45$ & 0.732 & $1285.41 \pm 88.56$ & $908.26 \pm 594.29$ & 0.146 \\
\hline $\mathrm{Na}$ & $4833.71 \pm 299.39$ & $4470.09 \pm 389.87$ & $0.1^{*}$ & $4588.18 \pm 101.27$ & $4731.22 \pm 232.86$ & 0.211 & $4362.16 \pm 528.49$ & $4293.67 \pm 217.34$ & 0.776 \\
\hline $\mathrm{Si}$ & $556.4 \pm 74.22$ & $555.58 \pm 96.53$ & 0.987 & $586.31 \pm 102.62$ & $632.12 \pm 66.88$ & 0.381 & $608.79 \pm 53.63$ & $1046.83 \pm 499.28$ & $0.059^{*}$ \\
\hline $\mathrm{Zn}$ & $1302.34 \pm 57.82$ & $1333.33 \pm 148.45$ & 0.649 & $1333.13 \pm 125.87$ & $1262.74 \pm 74.93$ & 0.266 & $1195.84 \pm 31.38$ & $1278.31 \pm 102.6$ & $0.082^{*}$ \\
\hline As & $357.02 \pm 57.42$ & $331.16 \pm 19.2$ & 0.335 & $312.44 \pm 37.34$ & $374.72 \pm 60.21$ & $0.057^{*}$ & $335.47 \pm 39.31$ & $497.77 \pm 171.67$ & $0.047^{*}$ \\
\hline $\mathrm{Cd}$ & $3654.57 \pm 441.55$ & $4399.27 \pm 1132.91$ & 0.181 & $4336.48 \pm 126.76$ & $4244.9 \pm 1042.84$ & 0.839 & $4347.66 \pm 291$ & $3136.43 \pm 1379.26$ & $0.06^{*}$ \\
\hline Сo & $1117.42 \pm 147.38$ & $1259.14 \pm 147.04$ & 0.126 & $1273.06 \pm 170.98$ & $1247.04 \pm 133.73$ & 0.775 & $1112.75 \pm 37.37$ & $1463.05 \pm 426.81$ & $0.073^{*}$ \\
\hline $\mathrm{Cr}$ & $6835.71 \pm 1506.2$ & $9731.8 \pm 1079.24$ & $0.003^{*}$ & $8369.91 \pm 1761.01$ & $9240.18 \pm 425.15$ & 0.287 & $7849.12 \pm 1329.58$ & $9572.88 \pm 1876.23$ & $0.087^{*}$ \\
\hline $\mathrm{Ni}$ & $2484.15 \pm 234.61$ & $3131.57 \pm 707.18$ & $0.077^{*}$ & $2614.26 \pm 274.44$ & $2901.75 \pm 152.11$ & $0.049^{*}$ & $2993.54 \pm 295.17$ & $7287.26 \pm 6069.58$ & 0.111 \\
\hline $\mathrm{Pb}$ & $816.06 \pm 330.27$ & $712.28 \pm 254.13$ & 0.555 & $534.39 \pm 58.73$ & $583.92 \pm 65.23$ & 0.197 & $585.41 \pm 161.6$ & $1343.13 \pm 1008.31$ & $0.095^{*}$ \\
\hline $\mathrm{Sb}$ & $41.45 \pm 19.21$ & $270.81 \pm 455.41$ & 0.272 & $53.52 \pm 59.27$ & $29.06 \pm 4.79$ & 0.359 & $25.83 \pm 2.67$ & $159.95 \pm 157.13$ & $0.065^{*}$ \\
\hline Se & $968.42 \pm 187.78$ & $1577.55 \pm 1017.44$ & 0.205 & $877.3 \pm 229.69$ & $850.41 \pm 105.86$ & 0.8 & $798.42 \pm 177.76$ & $1536.78 \pm 898.85$ & $0.074^{*}$ \\
\hline $\mathrm{Ti}$ & $180,279.31 \pm 10,342.08$ & $205,040.55 \pm 34,090.69$ & 0.14 & $187,846.41 \pm 19,091.61$ & $183,253.95 \pm 6786.35$ & 0.598 & $174,537.76 \pm 7871.31$ & $226,973.61 \pm 77,000.29$ & 0.122 \\
\hline V & $187.21 \pm 225.46$ & $511.57 \pm 212.54$ & $0.028^{*}$ & $349.2 \pm 297.56$ & $616.95 \pm 134.45$ & $0.072^{*}$ & $479.38 \pm 297.65$ & $1737.51 \pm 1483.6$ & $0.067^{*}$ \\
\hline & & May 2 & & & & & & & \\
\hline & & CIL & & & & IV & & & $\mathrm{p}$ \\
\hline $\mathrm{Al}$ & & & \pm 15.21 & & & $299.04 \pm$ & & & $0.016^{*}$ \\
\hline B & & & \pm 11.12 & & & $68.08 \pm$ & & & 0.85 \\
\hline $\mathrm{Ca}$ & & & \pm 723.85 & & & $8215.32 \pm$ & 2.16 & & 0.45 \\
\hline $\mathrm{Cu}$ & & & \pm 23.41 & & & $144.4 \pm$ & & & $0.016^{*}$ \\
\hline $\mathrm{Fe}$ & & & \pm 90.72 & & & $909.44 \pm$ & & & 0.101 \\
\hline K & & 12,73 & \pm 1512.59 & & & $8276.15 \pm$ & & & $0^{*}$ \\
\hline Mg & & & \pm 490.95 & & & $7268.25 \pm$ & & & $0.007^{*}$ \\
\hline $\mathrm{Mn}$ & & & \pm 34 & & & $227.16 \pm$ & & & $0.088^{*}$ \\
\hline $\mathrm{Na}$ & & & \pm 503.75 & & & $3541.63 \pm$ & & & $0.041^{*}$ \\
\hline $\mathrm{Si}$ & & & \pm 72.29 & & & $573.38 \pm$ & & & 0.25 \\
\hline $\mathrm{Zn}$ & & & \pm 65.55 & & & $488.96 \pm$ & & & $0.045^{*}$ \\
\hline As & & & \pm 67.3 & & & $480.17 \pm$ & & & $0^{*}$ \\
\hline $\mathrm{Cd}$ & & & \pm 48.73 & & & $520.97 \pm$ & & & $0^{*}$ \\
\hline Co & & & \pm 59.04 & & & $837.95 \pm$ & & & $0.002^{*}$ \\
\hline $\mathrm{Cr}$ & & & \pm 989.02 & & & $7952.76 \pm$ & & & 0.201 \\
\hline $\mathrm{Ni}$ & & & \pm 354.61 & & & $5216.77 \pm$ & 4.54 & & 0.461 \\
\hline $\mathrm{Pb}$ & & & \pm 465.77 & & & $516.76 \pm$ & & & $0^{*}$ \\
\hline $\mathrm{Sb}$ & & & \pm 13.44 & & & $78.57 \pm$ & & & $0.093^{*}$ \\
\hline Se & & & \pm 125.07 & & & $303.57 \pm$ & & & 0.173 \\
\hline $\mathrm{Ti}$ & & 247,36 & $\pm 19,466.26$ & & & $59,453.22 \pm$ & 523.3 & & 0.218 \\
\hline V & & & \pm 85.17 & & & $1258.24 \pm$ & & & $0.009^{*}$ \\
\hline
\end{tabular}




\section{Version définitive du manuscrit publiée dans / Final version of the manuscript published in : \\ Environment International (2013) Vol. 60, p. 31- 41, DOI: 10.1016/j.envint.2013.07.002 \\ Journal homepage: www.elsevier.com/locate/envint}

metals were then subjected to an evolution during the observation year. In May 2009, significant differences between the two sites were found for four metals ( $\mathrm{p}<0.1$ ), $\mathrm{Na}, \mathrm{Cr}, \mathrm{Ni}$ and $\mathrm{V}$, higher levels being found at the RAV site except for Na. In August 2009, As, Ni and V exhibited significant differences with higher levels at the RAV site $(p<0.1)$. In November 2009, the number of metals whose levels differed significantly between the two sites increased markedly. Significant differences were found for $\mathrm{Al}, \mathrm{B}, \mathrm{Cu}, \mathrm{Fe}, \mathrm{K}, \mathrm{Si}, \mathrm{Zn}, \mathrm{As}, \mathrm{Cd}, \mathrm{Co}, \mathrm{Cr}, \mathrm{Pb}, \mathrm{Sb}$, Se and V $(\mathrm{p}<0.1$ ), with higher levels at the RAV site for Al, Fe, Si, Zn, As, Co, Cr, $\mathrm{Pb}, \mathrm{Sb}, \mathrm{Se}$ and $\mathrm{V}$. In May 2010, large number of metals differed significantly between the two sites. It was possible to observe a difference for $\mathrm{Al}, \mathrm{Cu}, \mathrm{K}, \mathrm{Mg}, \mathrm{Mn}, \mathrm{Na}, \mathrm{Zn}, \mathrm{As}, \mathrm{Cd}, \mathrm{Co}, \mathrm{Pb}, \mathrm{Sb}$ and $\mathrm{V}(\mathrm{p}<0.1)$, with higher levels at the RAV site for Al, Mn, Zn, As, Cd, Co and V. None of the pesticides screened were detected in the bees at any of the sampling time points (data not shown).

\subsection{Biological variability}

Biological variability is known to affect biomarker responses and could be characterized with satisfactory precision. Although seasonal variability is a type of biological variability, we chose to analyse it separately (see below). Numerous precautions were taken when choosing the honeybees in order to limit biological variability: all the hives possessed a queen of one year, were carefully controlled regarding their sanitary state, and were equivalent in terms of population and development, and the honeybees collected were only foragers sampled at the hive entrance after their return flight. Moreover, all the honeybees possessed the same maternal origin, as only one mitochondrial profile was found in the six hives. This profile was the same as the A1 profile found by Franck and colleagues in that region, and referred to as belonging to a race of the African lineage A. mellifera unicolor (Franck et al., 2001). We were able to estimate two types of biological variability, related to: (i) the activities of honeybee biomarkers within each hive (intra-hive) and (ii) the mean of honeybee activity from one hive to another (inter-hive). In order to compare these sources of variability, coefficients of variation were calculated (Table 3). Intra-hive variability was described by the dispersion of the honeybee activity values for each hive at each sampling period. Inter-hive variability corresponded to a comparison of average honeybee activity in each hive at a given sampling period. The results revealed specific intra-hive and interhive variabilities for each biomarker, independently of the month, in the following order: AChE $<$ GST $<$ ALP. Unlike other biomarkers, MT displayed more heterogeneous intra-hive variability between months. Moreover, inter-hive variability was generally slightly higher than intra-hive variability, probably because of the internal characteristics of the hive and the slightly different foraging areas covered. The main

\section{Table 3}

Intra and inter-hive biological variability regarding biomarker activities at each month. Coefficients of variation (SD/mean) were calculated for each hive and the means for hives were calculated to assess intra-hive variability, $\mathrm{n}=360$. Coefficients of variation were calculated on the mean values of hives in order to assess inter-hive variability ( $n=30)$.

\begin{tabular}{llrllll}
\hline $\begin{array}{l}\text { Sampling } \\
\text { period }\end{array}$ & $\begin{array}{l}\text { Type of biological } \\
\text { variability }\end{array}$ & $\begin{array}{l}\text { AChE } \\
(\%)\end{array}$ & $\begin{array}{l}\text { ALP } \\
(\%)\end{array}$ & $\begin{array}{l}\text { GST } \\
(\%)\end{array}$ & $\begin{array}{l}\text { Head } \\
\text { MT (\%) }\end{array}$ & $\begin{array}{l}\text { Midgut } \\
\text { MT (\%) }\end{array}$ \\
\hline May 2009 & Intra-hive & 8.62 & 24.99 & 14.44 & 19.48 & 21.69 \\
& Inter-hive & 25.19 & 45.45 & 29.78 & 15.13 & 15.13 \\
August 2009 & Intra-hive & 8.75 & 22.98 & 18.85 & 15.01 & 12.24 \\
& Inter-hive & 24.64 & 33.11 & 58.07 & 12.55 & 12.55 \\
November 2009 & Intra-hive & 8.70 & 19.20 & 14.98 & 8.65 & 8.65 \\
& Inter-hive & 8.21 & 17.90 & 41.32 & 14.24 & 10.94 \\
February 2010 & Intra-hive & 8.80 & 17.13 & 14.82 & - & - \\
& Inter-hive & 11.48 & 10.76 & 26.57 & - & - \\
May 2010 & Intra-hive & 5.85 & 10.35 & 15.37 & 19.12 & 8.05 \\
& Inter-hive & 11.07 & 14.55 & 5.64 & 8.57 & 8.57 \\
\hline
\end{tabular}

outstanding question was whether biological variability introduced a confounding factor in the discrimination of sites.

\subsection{Profiles of biomarker response}

The evolution of biomarkers in bees from the CIL and RAV sites was followed for one year by sampling the honeybees every three months (Fig. 2). The temporal profiles of ALP, GST and AChE differed markedly at the two sites. For AChE and ALP, activity was lower in the urban RAV site throughout the observation period (Fig. 2A, B). Compared to May 2009, considered here as the baseline reference, ALP displayed a gradual decline at both sites, reaching $49.7 \%$ and $87.6 \%$ of activity in May 2010, respectively. Whereas ALP at the CIL site tended to return to baseline activity, RAV ALP appeared to reach stability at a lower value. AChE activity decreased at the RAV site from $33.6 \%$ in November 2009 to 22.9\% in May 2010, whereas CIL AChE activity appeared to be steadier during the observation period. For GST, an enzyme induced rapidly by pollutants, activity was similar at the two sites during the first three months and then rose at the RAV site (Fig. 2C). In May 2010, GST showed an increase of $43.0 \%$ compared to May 2009 at the CIL site, whilst a marked increase of $139.6 \%$ was observed at the RAV site. After a slight fall in August 2009, MT levels in the honeybee head appeared to remain steady at the reference level in the bees from the CIL site (Fig. 2D). At the RAV site, MT levels remained steady between May and November 2009 and then displayed an increase of 53.6\% over baseline in May 2010. In the midgut, MT levels increased between May and August 2009 to reach 140.5\% and 143.4\% of baseline at the CIL and RAV sites, respectively (Fig. 2E). MT levels then remained stable until May 2010 at both sites. Despite the fact that MT levels tended to follow the same trend at both the CIL and RAV locations, a significant difference was noted in May 2010 between the two sites, with contrasting profiles in the midgut and head.

The activities and concentrations of the biomarkers are presented in Tables 4 and 5. The tissue and specific activity responses of ALP, AChE and GST appeared to be statistically different at the CIL and RAV sites at each sampling period and for all biomarkers ( $p<0.01$ ), except for ALP and AChE in February 2010 (Table 4). Midgut MT tissue levels were also statistically different between the CIL and RAV sites at each sampling period ( $\mathrm{p}<0.05$ ), whereas head MT levels appeared to be statistically different only in May and November 2009 (Table 5). Compared to the CIL site, RAV displayed lower AChE activities (except in May 2009), higher ALP activities and midgut MT tissue levels (except in May 2010) and higher GST activities in November 2009 and February 2010. For ALP, AChE and GST, the specific and tissue response patterns were similar. For MT, the profiles of specific concentrations did not always follow the profiles of tissue concentrations. And for specific concentrations, head MT levels only appeared to be statistically different between the CIL and RAV sites in August and November 2009 $(\mathrm{p}<0.05)$.

\subsection{Effect of site and season on biomarker activity}

In order to clarify whether variations in biomarkers could be ascribed to the anthropogenic environment despite seasonal variations, $\mathrm{r}^{2}$ contributions were calculated to quantify that part of biomarker variability due to the site and/or season. The results showed that the season was the main effect observed for all biomarkers: the $r^{2}$ contribution of season was higher than the $\mathrm{r}^{2}$ contribution of site (Table 6$)$. This effect could be graded as follows: ALP $(0.462)>$ MT $(0.438-0.392)>$ AChE $(0.232)>$ GST (0.115). However, the results also confirmed the overall influence of site for AChE, GST, ALP and midgut MT $(p<0.05$; Table 6 ). The analysis also indicated a significant interaction between the site and season effects on each biomarker ( $p<0.05$; Table 6). The contribution of the site effect was greater in August for AChE (0.450), ALP (0.644), GST (0.507) and head MT (Table 7). 
Table 4

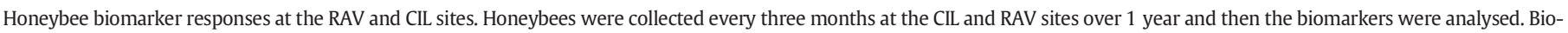

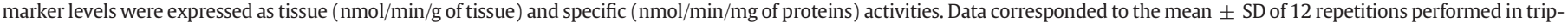
licate (180 honeybee samples per site).

\begin{tabular}{|c|c|c|c|c|c|c|c|c|c|c|}
\hline \multirow[t]{2}{*}{ Sampling period } & \multirow[t]{2}{*}{ Activities } & \multicolumn{3}{|l|}{ AChE } & \multicolumn{3}{|l|}{ ALP } & \multicolumn{3}{|l|}{ GST } \\
\hline & & CIL & RAV & $\mathrm{p}$ & CIL & RAV & $\mathrm{p}$ & CIL & RAV & $\mathrm{p}$ \\
\hline \multirow[t]{2}{*}{ May 2009} & Tissue & $3016.8 \pm 371.2$ & $3913.8 \pm 824.3$ & $1.10^{-6}$ & $237.1 \pm 70.2$ & $362.7 \pm 111.2$ & $1.10^{-6}$ & $4925.0 \pm 1333.7$ & $2651.5 \pm 415.0$ & $1.10^{-8}$ \\
\hline & Specific & $22.9 \pm 0.7$ & $27.7 \pm 8.9$ & 0.003 & $4.5 \pm 0.6$ & $9.0 \pm 3.1$ & $1.10^{-11}$ & $96.8 \pm 20.3$ & $68.6 \pm 11.4$ & $1.10^{-5}$ \\
\hline \multirow[t]{2}{*}{ August 2009} & Tissue & $4110.2 \pm 821.9$ & $3024.1 \pm 349.8$ & $1.10^{-7}$ & $217.1 \pm 30.7$ & $298.5 \pm 84.9$ & $1.10^{-5}$ & $4816.3 \pm 1896.7$ & $1673.6 \pm 614.9$ & $1.10^{-13}$ \\
\hline & Specific & $29.5 \pm 6.1$ & $21.1 \pm 2.6$ & $1.10^{-9}$ & $5.1 \pm 0.6$ & $9.1 \pm 1.1$ & $1.10^{-16}$ & $114.9 \pm 44.4$ & $48.8 \pm 18.0$ & $1.10^{-11}$ \\
\hline \multirow[t]{2}{*}{ November 2009} & Tissue & $3074.9 \pm 513.9$ & $2600.5 \pm 332.3$ & $1.10^{-4}$ & $173.0 \pm 27.4$ & $219.6 \pm 33.9$ & $1.10^{-5}$ & $2138.1 \pm 1202.1$ & $3551.8 \pm 797.3$ & $1.10^{-6}$ \\
\hline & Specific & $30.5 \pm 2.1$ & $27.8 \pm 1.2$ & $1.10^{-3}$ & $5.4 \pm 1.2$ & $6.9 \pm 0.4$ & $1.10^{-6}$ & $60.9 \pm 13.9$ & $108.3 \pm 34.3$ & $1.10^{-9}$ \\
\hline \multirow[t]{2}{*}{ February 2010} & Tissue & $3157.6 \pm 205.6$ & $3031.9 \pm 221.5$ & 0.20 & $161.3 \pm 23.5$ & $164.7 \pm 34.5$ & 0.366 & $4071.5 \pm 1465.6$ & $5361.4 \pm 2353.3$ & 0.001 \\
\hline & Specific & $23.2 \pm 1.1$ & $20.1 \pm 2.2$ & $1.10^{-6}$ & $2.8 \pm 0.3$ & $2.9 \pm 0.4$ & 0.550 & $67.9 \pm 21.5$ & $90.8 \pm 16.0$ & $1.10^{-6}$ \\
\hline \multirow[t]{2}{*}{ May 2010} & Tissue & $3320.1 \pm 359.2$ & $3019.1 \pm 241.6$ & 0.002 & $207.6 \pm 15.1$ & $180.1 \pm 16.1$ & $1.10^{-4}$ & $7047.2 \pm 1007.6$ & $6352.1 \pm 567.6$ & 0.026 \\
\hline & Specific & $28.3 \pm 1.6$ & $24.1 \pm 2.3$ & $1.10^{-11}$ & $3.5 \pm 0.6$ & $3.0 \pm 0.2$ & 0.004 & $114.4 \pm 6.9$ & $105.5 \pm 0.1$ & 0.003 \\
\hline
\end{tabular}

The confusion matrix resulting from the "leave-one-out" test showed an overall classification accuracy of $89 \%$. The analysis of MT and other biomarkers (AChE, ALP and GST) was performed on the same honeybees from a same hive. At the time of sampling, the honeybees were divided into two groups (one for AChE, ALP and GST and a second for MT). Consequently, decision rules were applied to mean biomarker activities per hive and per month, in order to integrate MT in the classification tree (Fig. 4). The results produced a simpler classification tree. Two biomarkers appeared to be highly discriminating: ALP and MT. They were the two complementary biomarkers that determined, with a low error rate (17\%), the site to which the hives belonged. Hives displaying ALP $>6.82 \mathrm{nmol} / \mathrm{min} / \mathrm{mg}$ were correctly classified at the RAV site and hives displaying MT $<21.78 \mu \mathrm{g} / \mathrm{mg}$ were correctly identified as belonging to the CIL site. The final terminal node corresponding to hives displaying $\mathrm{ALP}<6.82 \mathrm{nmol} / \mathrm{min} / \mathrm{mg}$ and $\mathrm{MT}>21.78 \mathrm{Ug} / \mathrm{mg}$ did not clearly identify the site of origin but tended to correspond to hives located at the more contaminated site, RAV. In summary, these decision rules satisfactorily classified the RAV site with $100 \%$ accuracy. Hives from the CIL site were well classified as belonging to this site, with $67 \%$ of accuracy.

\section{Discussion}

The aim of this study was to determine the potential for the use of honeybee biomarkers to assess environmental quality. This is the first study to have explored the responses of a battery of biomarkers in the honeybee collected in different anthropogenic contexts. The results revealed significant differences in the evolution of neural and metabolic biomarkers (AChE, GST, ALP and MT) in bees sampled at different locations. These biomarkers displayed specific profiles that could enable the discrimination of weakly and markedly anthropised sites.

To assess environmental health, any modulation of biomarkers must be attributable to the effect of pollutants and not to natural variations linked to developmental, physiological or genetic parameters. It is widely accepted that the effects of pollutants can differ as a function of the metabolic status and physiology of individuals. For example, a clear gender effect was observed regarding metabolic biomarker responses with high values in a study on Gasterosteus aculeatus L. males (Sanchez et al., 2007). Moreover, physiological effects are the most pronounced during the breeding period, as observed with GST activity levels in Anguilla anguilla and Mugul cephalus (Gorbi et al., 2005). In the honeybee, it has been shown that significant variability may be due to the developmental stage of both workers and the queen (Polyzou et al., 1997). However, compared to other species, biological variability can easily be reduced in the honeybee by sampling foragers only. This enables a reduction in variations linked to: (i) gender, (ii) spawning period and (iii) age, which markedly modulates polyethism in the colony. Moreover, foragers represent primarily exposed individuals in a colony and their use can increase the pertinence of potential biomarker responses. According to Deviller et al. (2005), GST exhibited greater biological variability than ALP and AChE. This result could be explained in part by the role of biomarkers. Metabolic biomarkers are directly involved in the detoxification process and display greater variability than neural biomarkers because organisms are often in contact with numerous pollutants. For all biomarkers, biological variability can be attributed in part to the type of biomarker, the existence of half sibs in a colony due to the fecundation of the queen by different males, the age of foragers (which can range from 18 to 24 days in the summer) (Abou-Donia et al., 2004; Dukas, 2008) and the foraging area of honeybees, which can vary between individuals and between colonies. In the present study, intra-hive and inter-hive variabilities appeared to be equivalent, except for AChE which displayed lower intra-hive variability. This result enabled a conclusion as to the correct homogeneity of the colonies studied. It therefore appeared more pertinent to consider the responses of several colonies, which offered better coverage of the areas under study. Moreover, honeybees are subjected to seasonal variations which cause changes to various physiological

Table 5

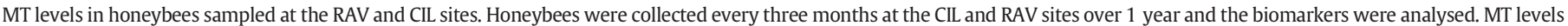
are expressed in $\mu \mathrm{g} / \mathrm{g}$ of tissue and $\mathrm{mg} / \mathrm{g}$ of proteins. Data corresponded to the mean \pm SD of 12 repetitions performed in triplicate (180 honeybee samples per site).

\begin{tabular}{|c|c|c|c|c|c|c|c|}
\hline \multirow[t]{2}{*}{ Sampling period } & \multirow[t]{2}{*}{ MT levels } & \multicolumn{3}{|l|}{ Head MT } & \multicolumn{3}{|l|}{ Midgut MT } \\
\hline & & CIL & RAV & $\mathrm{p}$ & CIL & RAV & $\mathrm{p}$ \\
\hline \multirow[t]{2}{*}{ May 2009} & Tissue & $378.7 \pm 71.8$ & $295.7 \pm 45.5$ & 0.01 & $776.7 \pm 123.8$ & $868.3 \pm 84.4$ & 0.031 \\
\hline & Specific & $10.8 \pm 1.3$ & $15.5 \pm 7.1$ & 0.114 & $96.7 \pm 13.6$ & $112.7 \pm 15.7$ & 0.002 \\
\hline \multirow[t]{2}{*}{ August 2009} & Tissue & $283.0 \pm 28.6$ & $258.6 \pm 58.3$ & 0.114 & $1091.2 \pm 129.3$ & $1244.8 \pm 166.4$ & 0.008 \\
\hline & Specific & $15.4 \pm 2.5$ & $22.4 \pm 8.4$ & 0.043 & $149.2 \pm 25.9$ & $166.8 \pm 29.3$ & 0.1 \\
\hline \multirow[t]{2}{*}{ November 2009} & Tissue & $332.7 \pm 50.9$ & $299.5 \pm 73.0$ & 0.018 & $873.2 \pm 76.0$ & $961.6 \pm 112.0$ & 0.019 \\
\hline & Specific & $29.1 \pm 7.2$ & $24.4 \pm 4.6$ & 0.031 & $152.1 \pm 15.9$ & $141.6 \pm 12.0$ & 0.019 \\
\hline \multirow[t]{2}{*}{ February 2010} & Tissue & - & - & & - & - & \\
\hline & Specific & - & - & & - & - & \\
\hline \multirow[t]{2}{*}{ May 2010} & Tissue & $411.4 \pm 37.5$ & $454.3 \pm 93.9$ & 0.448 & $892.3 \pm 74.1$ & $816.6 \pm 79.4$ & 0.01 \\
\hline & Specific & $21.7 \pm 4.9$ & $19.1 \pm 5.3$ & 0.146 & $152.3 \pm 36.2$ & $167.0 \pm 35.2$ & 0.184 \\
\hline
\end{tabular}


Table 6

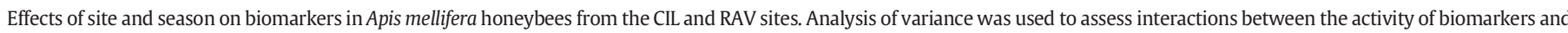

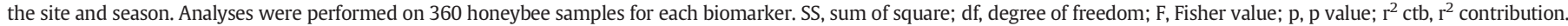

\begin{tabular}{|c|c|c|c|c|c|c|c|c|c|c|c|c|c|c|c|}
\hline \multirow[t]{2}{*}{ Biomarkers } & \multicolumn{5}{|c|}{ Site effect } & \multicolumn{5}{|c|}{ Season effect } & \multicolumn{5}{|c|}{ Site $\times$ season } \\
\hline & SS & df & $\mathrm{F}$ & $\mathrm{p}$ & $r^{2} c t b$ & SS & df & $\mathrm{F}$ & $\mathrm{p}$ & $r^{2}$ ctb & SS & df & $\mathrm{F}$ & $\mathrm{p}$ & $r^{2} \mathrm{ctb}$ \\
\hline AChE & 678.5 & 1 & 47.2 & 0.000 & 0.077 & 2042.5 & 4 & 35.5 & 0,000 & 0.232 & 1353.5 & 4 & 23.5 & 0.000 & 0.154 \\
\hline ALP & 344.0 & 1 & 199.4 & 0.000 & 0.143 & 1113.8 & 4 & 161.4 & 0.000 & 0.462 & 357.8 & 4 & 51.9 & 0.000 & 0.148 \\
\hline GST & 4206.0 & 1 & 6.9 & 0.009 & 0.011 & $45,240.0$ & 4 & 18.5 & 0.000 & 0.115 & $138,007.0$ & 4 & 56.4 & 0.000 & 0.351 \\
\hline MT in head & 44.0 & 1 & 1.4 & 0.241 & 0.005 & 3365.5 & 3 & 35.4 & 0.000 & 0.392 & 857.8 & 3 & 9.0 & 0.000 & 0.100 \\
\hline MT in intestine & 3228.0 & 1 & 5.3 & 0.023 & 0.020 & $71,374.0$ & 3 & 38.7 & 0.000 & 0.438 & 4811.0 & 3 & 2.6 & 0.054 & 0.030 \\
\hline
\end{tabular}

parameters such as neurotransmitter levels, protein metabolism or juvenile hormone titres which might modify the effects of xenobiotics (Crailsheim, 1986). In this study, all metabolic and neural biomarkers were subject to seasonal variations. Moreover, the site effect could differ depending on the season for all biomarkers. GST activity displayed a stronger interaction between site and season $\left(r^{2}=0.351\right.$, Table 6$)$. Despite biological variations due to the seasonal and internal characteristic of colonies, a site effect was clearly identified during this study, and was confirmed by two-way factorial analysis. The similarity of the seasonal patterns at the RAV and CIL sites, observed with respect to GST, ALP and AChE during a year, may have contributed to the distinctiveness of the sites. Interestingly, all biomarkers displayed a stronger site effect in August, probably due to the greater abundance of pollutants at that period (Table 7). According to Jolly et al. (2012), the response profiles of the biomarkers could be explained by the seasonality of pollution due to local practices in the areas under investigation.

Several authors have demonstrated a high degree of GST activity induction following exposure to various contaminants such as metals, pesticides, PAH and PCB (Garner and Di Giulio, 2012; Papadopoulos et al., 2004; Yu et al., 2012). Sanchez et al. (2006) also showed a 75\% induction of the control in the stickleback after exposure to Agral $90 \AA$ (polyethoxylated nonylphenol) for 21 days at $1000 \mu \mathrm{g} / \mathrm{L}$. However, after combined exposure to Agral $90 \AA$ and the herbicide Diquat (1000:444 $\mu \mathrm{g} / \mathrm{L}$ ), induction was more marked and represented $300 \%$ of the control activity. Amongst the numerous insecticides that we tested under laboratory conditions, maximum GST induction in the honeybee was moderated. For example, after exposure to thiamethoxam at a dose of 2.6 ng.bee ${ }^{-1}$, the induction of specific activity represented $20 \%$ of the control activity (Badiou-Bénéteau et al., 2012). However, the evolution profile of GST under environmental conditions showed a maximum of induction of approximately $140 \%$ of initial activity at the RAV site in May 2010. This revealed that the induction potential of GST under environmental conditions was much greater than that expected in the laboratory. Similarly, under laboratory conditions, no effect was observed on ALP after exposure to thiamethoxam at 2.6, 5.1 and 51.2 ng.bee ${ }^{-1}$ (Badiou-Bénéteau et al., 2012), and only limited effects were observed after exposure to fipronil (unpublished data) at 0.58 and 0.27 ng.bee ${ }^{-1}$ whereas considerable induction was observed at the RAV site. Maximum

Table 7

Effect of the site on biomarkers Apis mellifera honeybees from the CIL and RAV sites during the observation period. Analysis of variance was used to assess interactions between the activity of biomarkers and the site as a function of the month and the $\mathrm{r}^{2}$ contribution of the site. Analyses were performed on 72 honeybee samples for each biomarker, each month.

\begin{tabular}{llllll}
\hline Month & AChE & ALP & GST & \multicolumn{2}{l}{ MT } \\
\cline { 5 - 6 } & & & & Head & Midgut \\
\hline May 2009 & 0.150 & 0.545 & 0.247 & 0.180 & 0.239 \\
August & 0.450 & 0.644 & 0.507 & 0.255 & 0.097 \\
November & 0.168 & 0.272 & 0.431 & 0.140 & 0.127 \\
February & 0.276 & 0.006 & 0.286 & - & - \\
May 2010 & 0.477 & 0.114 & 0.122 & 0.061 & 0.043
\end{tabular}

induction of around 200\% was observed between May 2009 and May 2010. By contrast, the maximum response of AChE, observed at the RAV site, appeared to be moderate (a reduction of 20\% in May 2010 compared to May 2009, p > 0.01) when compared to GST and ALP, but its activity was more stable and its natural variability lower. Consequently, although its modulation was moderate, $\mathrm{AChE}$ remained the better biomarker in the honeybee because of its stable activity and low variability (see also Badiou et al., 2008; Badiou-Bénéteau et al., 2012). The results showed that the induction potential of honeybee biomarkers could be revealed partially under laboratory conditions. However, differences in biomarker responses could be seen between controlled and natural conditions. At similar levels of exposure, these differences could in part be explained by the presence of other contaminants and interactions with these latter.

The evolution profiles of MT displayed marked differences between the head and midgut. In the midgut, the initial MT concentrations are lower at the CIL site than at the RAV site. MT concentrations remained lower between May 2009 and February 2009 but then rose in May 2010. However, there was no great difference between the relative evolution profiles in bees from the CIL and RAV sites. Conversely, in the head, MT concentrations were higher at the CIL site, except in May 2010. Relative MT values were higher at the RAV site, and the relative increase in MT concentrations observed from August 2009 was more pronounced at the RAV site, leading to a higher absolute level at the RAV site after one year. The very similar relative evolution profiles of midgut MT levels observed in bees from the RAV and CIL sites were somewhat surprising because the digestive tract is the first site to be exposed to pollutants following the ingestion of contaminated food. This contrasts with the ability of insect gut MT to bind non-essential trace elements such as cadmium (Hensbergen et al., 2000). Conversely, the higher relative head MT values observed at the RAV site may have reflected a greater ability of the brain to respond to exposure to nonessential trace elements. This could be explained by the fact that the brain is a critical organ whose defences against stressors are particularly efficient. MT could therefore be involved in the detoxification of nonessential trace elements, and especially of heavy metals that induce neurotoxicity (Dallinger, 1996). This is consistent with the involvement of MT in preventing or repairing injuries in a brain subjected to different types of impairments (Arellano-Ruiz et al., 2012; Kim et al., 2012; Leung et al., 2012; Sohn et al., 2012.

The volcanic activity of La Reunion island gives rise to high metal concentrations in the environment that increase the probability of metals being recovered from bioindicator species, as observed during this study. The difference of metal profiles between the CIL and RAV sites evolved during the year of observation. As a function of time, the number of metals displaying significant differences between the two sites increased gradually to reach a maximum in May 2010, a month during which the greatest differences between the two sites were observed for almost all biomarkers. It may therefore be legitimate to correlate the evolution of metal profiles to those of biomarkers, especially MT. This is particularly true if we consider that most of the metals for which significant differences were seen between the CIL and RAV sites are linked to human and/or volcanic activities. However, although the impacts of metals on different physiological systems are relatively well documented in the literature (e.g. Hensbergen et al., 2000; Yu 


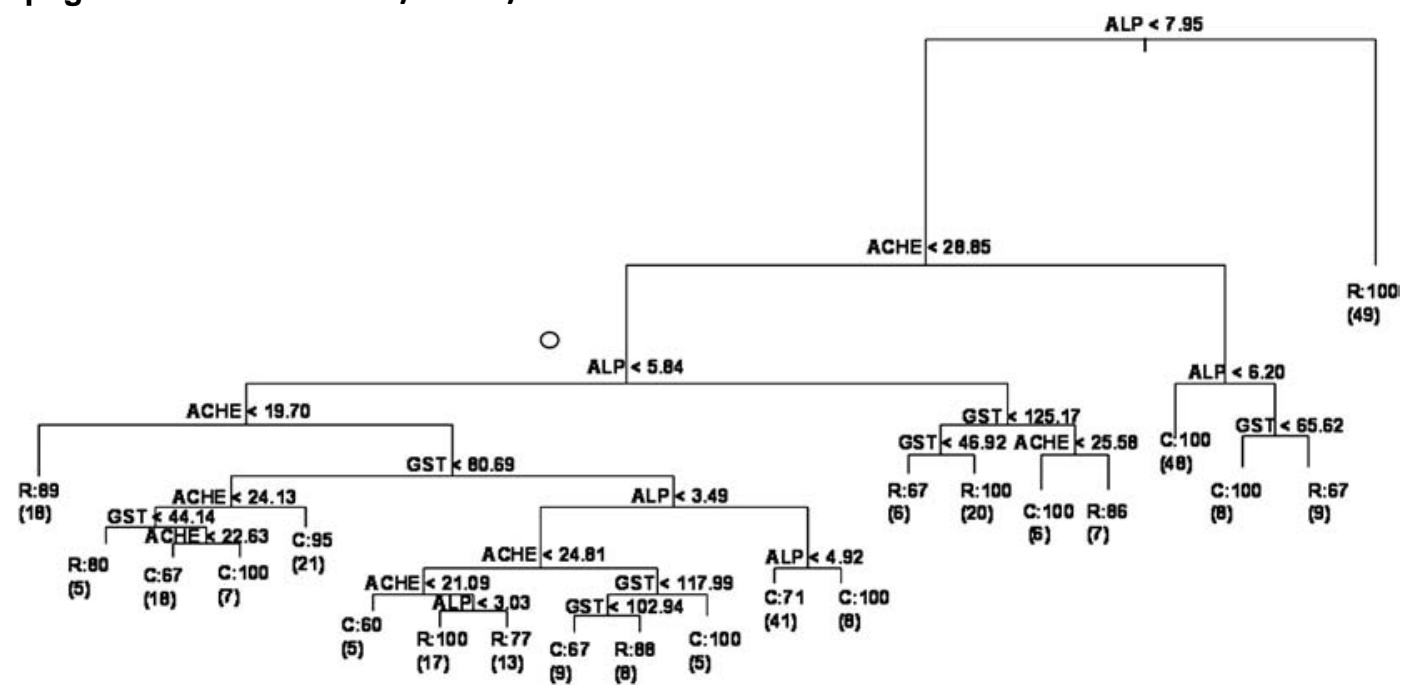

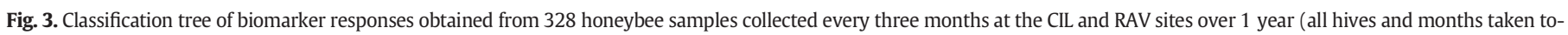
gether). Terminal nodes identify the site or dominant site with its corresponding associated percentage and number of honeybees.

et al., 2012), changes to the biomarker profiles may also have been due to other pollutants such as xenobiotic organic substances, which were not investigated during this study. In fact, the most important piece of information is that honeybee colonies placed in different anthropogenic contexts may display significant differences in terms of their biomarker profiles that could be accentuated by the time spent in these different environments.

The environmental significance of biomarker responses seems easy to assess when biomarker activity is modulated as was generally observed in the contaminated area, such as such as an increase for GST and a decrease for $\mathrm{AChE}$, for example. The relationship between the presence of contaminants and the effects observed is more difficult to establish when deviations from the usual modulation patterns are observed for biomarkers. Variations in activity may depend on the characteristics of each study, and inhibition or activation (or even both) have been reported in tissues from different organisms (Costa et al., 2008). In our work, it was noteworthy that the selected biomarkers were modulated according to the usual responses. Stronger effects on ALP, AChE

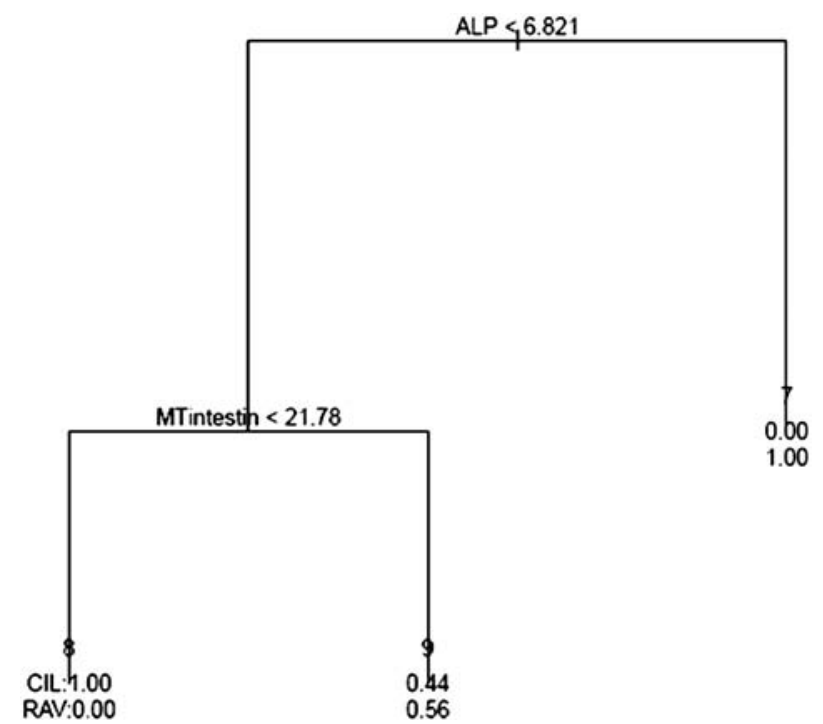

Fig. 4. Classification tree of biomarker responses obtained on samples from each hive every three months at the CIL and RAV sites over 1 year. The mean biomarker responses for each hive at each month were used to build the classification tree $(n=24)$. Terminal nodes identify the site or dominant site with its corresponding associated percentage and number of hives. and midgut MT tissue levels were observed at the RAV site, with a decrease of AChE and an increase in ALP and MT. A reduction of AChE activity is known to be an indicator of direct neurotoxic effects, particularly following exposure to organophosphate and carbamate pesticides (Galgani and Bocquene, 1990; Payne et al., 1996). In addition, metals, detergents and complex mixtures of pollutants can also decrease AChE activity, so that AChE constitutes a general biomarker of neurotoxic effects (Bandyopadhyay, 1982; Frasco et al., 2005). The relationship between exposure to neurotoxic compounds and a reduction in AChE activity has been demonstrated in numerous studies (Fulton and Key, 2001). The low AChE activity seen in honeybees collected at the RAV site thus suggested the presence of more neurotoxic compounds at RAV site than at CIL. However, the decrease in AChE activity was not a systematic response to pollutants and, depending on the pollutant, a marked increase of AChE might also occur, as has been observed with pyrethroids (Badiou et al., 2008). Moreover, ALP, GST and MTs are involved in cellular defence processes that are typically reflected by an increase of their activities after exposure to xenobiotics (Bounias et al., 1996; Durou et al., 2007). Their respective functions imply that responses occur with many different contaminants, such as metals (Bounias et al., 1996; Martín-Díaz et al., 2008; Stone et al., 2002). For example, MT is considered to be a potential biomarker of exposure to heavy metals in the terrestrial environment (Hensbergen et al., 2000). Similarly to AChE, ALP activity between May 2009 and February 2010 and midgut MT between May 2009 and November 2009 exhibited typical profiles with higher levels of activity at RAV than at the CIL site. The results appeared to be more contrasted for GST, where lower levels of activity were observed in May and August 2009 and in May 2010 at the RAV site. However, the results obtained with biomarkers strongly suggested that honeybees based in an anthropized area were subjected to sublethal stresses involving both oxidative stress and detoxification processes, with the occurrence of neurotoxic compounds. Moreover, the results of metals analyses revealed a prevalence of metals at the RAV site, suggesting that metals represent good candidates to modulate biomarkers.

The translation of biological data into environmental information is sometimes problematic because it is difficult to distinguish between the effects of temporal and spatial variability on variations in biomarker levels. A pertinent approach can consist in integrating these parameters into a site discrimination model to reveal site-specific contamination patterns that are reliably discriminated by biomarker responses (Narbonne et al., 2005). Discriminant analysis (DA) and principal component analysis are widely recognised as multivariate statistical tools to investigate differences amongst sites and summarize responses 


\section{Version définitive du manuscrit publiée dans / Final version of the manuscript published in : \\ Environment International (2013) Vol. 60, p. 31- 41, DOI: 10.1016/ị.envint.2013.07.002 Journal homepage: www.elsevier.com/locate/envint}

(Falfushynska and Stolyar, 2009). However, these statistical analyses require that an unexplained part of data variation should be normally distributed, a condition rarely respected during field studies. Rulebased classification models appear to be more appropriate for a broad range of data distributions. These models were extensively described by Chèvre et al. (2003a). They are simple to express, invariant under monotonic parameter transformations, they account for qualitative factors and provide efficient classifiers. Instead of forming a minimal set of rules based on linear combinations of parameters (as is the case with DA), rule-based methods build logical combinations of single parameter conditions. During the present study, different discrimination methods were tested and especially two rule-based methods: a rough set (data not shown) and a classification tree (CT). Although these two methods produced a satisfactory classification, a better classification of honeybee biomarkers from the two sites was provided by the classification tree with accuracy reaching $89 \%$, which was very similar to that observed by Chèvre et al. (2003b). CT analysis showed that the set of biomarkers with marked significance included ALP and MT. The greater weight of ALP was underlined by the CT, insofar as honeybees exhibiting high ALP levels were rapidly identified as belonging to the more anthropogenic site, RAV: pure leaves were characterised by activities higher than $7.97 \mathrm{nmol} / \mathrm{min} / \mathrm{mg}$ of protein (higher than $6.82 \mathrm{nmol} / \mathrm{min} / \mathrm{mg}$ if an analysis of mean biomarker activities per hive was performed).

The data collected during this study enabled a discrimination between the two sites. Such discrimination constitutes the first step in the development of a honeybee index that could integrate data derived from numerous sites and applicable to both spatial and temporal studies. The design of honeybee risk assessment studies needs to be based on a model which integrates the variability of environmental pressures and honeybee physiology. Development of this index will facilitate the comparison of different sites and the identification of contaminated terrestrial sites so that environmental health can be assessed using the honeybee. The addition of other study sites and biomarkers should improve the discriminating power of the biomarkers and the robustness of the index (Sanchez et al., 2008; Schiedek et al., 2006). In this way, the development of specific biomarkers from biological systems or tissues specifically targeted by pollutants needs to be pursued in the honeybee and validated in different environmental contexts. As a result, it will be possible to propose a battery of biomarkers as a new tool for use under a multi-parametric approach in routine terrestrial biomonitoring programmes.

\section{Conclusion}

The purpose of this study was to evaluate two types of anthropogenic contexts using the discriminating potential of honeybee biomarkers previously validated under laboratory conditions. Urban and seminatural sites in La Reunion Island were studied for one year and the results clearly indicated local and seasonal differences in pollutant levels. Despite biological variations due to the seasonal and intrinsic characteristics of the honeybee colonies studied, the neural and metabolic response profiles of the biomarkers enabled good discrimination between the sites. These findings therefore validate the use of such biomarkers under field conditions. When compared to the CIL site only slightly affected by human activities, the urban RAV site displayed profiles of biomarker response that enable a conclusion regarding the environmental pressure to which the honeybees were subjected and the occurrence of neurotoxic compounds, amongst which metals were good candidates. A decision procedure was developed in order to distinguish the sampling sites and enabled excellent classification accuracy (89\%) for the data set. This field study constitutes the first report on use of the honeybee for the in situ assessment of environmental health using a multibiomarker approach.

\section{Acknowledgements}

This work was supported in part by SEOM of La Réunion Island. The authors would like to thank Eric Métas and Magdi Fridman for competent beekeeping, Patrick Turpin and Jean-Sébastien Dehecq for their expertise in geographic information.

\section{References}

Abou-Donia MB, Dechkovskaia AM, Goldstein LB, Abdel-Rahman A, Bullman SL, Khan WA. Co-exposure to pyridostigmine bromide, DEET, and/or permethrin causes sensorimotor deficit and alterations in brain acetylcholinesterase activity. Pharmacol Biochem Behav 2004;77:253-62.

Aguilera C, Del Pliego PG, Alfaro RM, Lazcano D, Cruz J. Pollution biomarkers in the spiny lizard (Sceloporus spp.) from two suburban populations of Monterrey, Mexico. Ecotoxicology 2012;21:2103-12.

Alaux C, Brunet JL, Dussaubat C, Mondet F, Tchamitchan S, Cousin M, et al. Interactions between Nosema microspores and a neonicotinoid weaken honeybees (Apis mellifera). Environ Microbiol 2010;12:774-82.

Arellano-Ruiz S, Rios C, Salgado-Ceballos H, Mendez-Armenta M, Del Valle-Mondragon L, Nava-Ruiz C, et al. Metallothionein-II improves motor function recovery and increases spared tissue after spinal cord injury in rats. Neurosci Lett 2012;514:102-5.

Badiou A, Meled M, Belzunces LP. Honeybee Apis mellifera acetylcholinesterase - a biomarker to detect deltamethrin exposure. Ecotoxicol Environ Saf 2008;69:246-53.

Badiou-Bénéteau A, Carvalho SM, Brunet JL, Carvalho GA, Buleté A, Giroud B, et al. Development of biomarkers of exposure to xenobiotics in the honeybee Apis mellifera: application to the systemic insecticide thiamethoxam. Ecotoxicol Environ Saf 2012;82: 22-31.

Bandyopadhyay R. Inhibition of acetylcholine esterase by permethrin \& its reversion by acetylthiocholine. Indian J Exp Biol 1982;20:488-91.

Belzunces LP, Toutant JP, Bounias M. Acetylcholinesterase from Apis mellifera head. Evidence for amphiphilic and hydrophilic forms characterized by Triton X-114 phase separation. Biochem J 1988;255:463-70.

Bounias M, Dujin N, Popeskovic DS. Sublethal effects of a synthetic pyrethroid, deltamethrin, on the glycemia, the lipemia, and the gut alkaline phosphatases of honeybees. Pestic Biochem Physiol 1985;24:149-60.

Bounias M, Kruk I, Nectoux M, Popeskovic D. Toxicology of cupric salts on honeybees. V. Gluconate and sulfate action on gut alkaline and acid phosphatases. Ecotoxicol Environ Saf 1996;35:67-76

Bradford MM. A rapid and sensitive method for the quantitation of microgram quantities of protein utilizing the principle of protein-dye binding. Anal Biochem 1976;72: 248-54.

Chauzat M-P, Carpentier P, Martel A-C, Bougeard S, Cougoule N, Porta P, et al. Influence of pesticides residues in honeybee (Hymenoptera: Apidae) colony health in France. Environ Entomol 2009;38:514-23.

Chevre N, Gagne F, Blaise C. Development of a biomarker-based index for assessing the ecotoxic potential of aquatic sites. Biomarkers 2003a;8:287-98.

Chevre N, Gagne F, Gagnon P, Blaise C. Application of rough sets analysis to identify polluted aquatic sites based on a battery of biomarkers: a comparison with classical methods. Chemosphere 2003b;51:13-3.

Costa MJ, Monteiro DA, Oliveira-Neto AL, Rantin FT, Kalinin AL. Oxidative stress biomarkers and heart function in bullfrog tadpoles exposed to Roundup Original. Ecotoxicology 2008;17:153-63.

Crailsheim K. Dependence of protein metabolism on age and season in the honeybee (Apis mellifica carnica Pollm). J Insect Physiol 1986;32:629-34.

Dallinger R. Metallothionein research in terrestrial invertebrates: synopsis and perspectives. Comp Biochem Physiol C Toxicol Pharmacol 1996;113:125-33.

Damiens G, His E, Gnassia-Barelli M, Quiniou F, Romeo M. Evaluation of biomarkers in oyster larvae in natural and polluted conditions. Comp Biochem Physiol C Toxicol Pharmacol 2004;138:121-8.

Decourtye A, Devillers J, Cluzeau S, Charreton M, Pham-Delègue M-H. Effects of imidacloprid and deltamethrin on associative learning in honeybees under semifield and laboratory conditions. Ecotoxicol Environ Saf 2004;57:410-9.

Deviller G, Palluel O, Aliaume C, Asanthi H, Sanchez W, Franco Nava MA, et al. Impact assessment of various rearing systems on fish health using multibiomarker response and metal accumulation. Ecotoxicol Environ Saf 2005;61:89-97.

Dukas R. Mortality rates of honeybees in the wild. Atherosclerosis 2008;55:252-5

Durou C, Poirier L, Amiard JC, Budzinski H, Gnassia-Barelli M, Lemenach K, et al. Biomonitoring in a clean and a multi-contaminated estuary based on biomarkers and chemical analyses in the endobenthic worm Nereis diversicolor. Environ Pollut 2007; $148: 445-58$.

Ellman GL, Courtney KD, Andres V, Feather-Stone RM. A new and rapid colorimetric determination of acetylcholinesterase activity. Biochem Pharmacol 1961;7:88-95.

Falfushynska HI, Stolyar OB. Responses of biochemical markers in carp Cyprinus carpio from two field sites in Western Ukraine. Ecotoxicol Environ Saf 2009;72:729-36.

Franck P, Garnery L, Loiseau A, Oldroyd BP, Hepburn HR, Solignac M, et al. Genetic diversity of the honeybee in Africa: microsatellite and mitochondrial data. Heredity 2001;86:420-30.

Frasco MF, Fournier D, Carvalho F, Guilhermino L. Do metals inhibit acetylcholinesterase (AChE)? Implementation of assay conditions for the use of AChE activity as a biomarker of metal toxicity. Biomarkers 2005;10:360-75.

Fulton MH, Key PB. Acetylcholinesterase inhibition in estuarine fish and invertebrates as an indicator of organophosphorus insecticide exposure and effects. Environ Toxicol Chem 2001;20:37-45. 
Environment International (2013) Vol. 60, p. 31- 41, DOI: 10.1016/j.envint.2013.07.002

\section{Journal homepage: www.elsevier.com/locate/envint}

Galgani F, Bocquene G. In vitro inhibition of acetylcholinesterase from four marine species by organophosphates and carbamates. Bull Environ Contam Toxicol 1990;45:243-9.

Garner LV, Di Giulio RT. Glutathione transferase pi class 2 (GSTp2) protects against the cardiac deformities caused by exposure to PAHs but not PCB-126 in zebrafish embryos. Comp Biochem Physiol C Toxicol Pharmacol 2012;155:573-9.

Garnery L, Solignac M, Celebrano G, Cornuet JM. A simple test using restricted PCR-amplified mitochondrial DNA to study the genetic structure of Apis mellifera. 1993;4:1016-21.

Gorbi S, Baldini C, Regoli F. Seasonal variability of metallothioneins, cytochrome P450, bile metabolites and oxyradical metabolism in the European eel Anguilla anguilla L. (Anguillidae) and striped mullet Mugil cephalus L. (Mugilidae). Arch Environ Contam Toxicol 2005;49:62.

Henry M, Froechen M, Maillet-Mezeray J, Breyne E, Allier F, Odoux JF, Decourtye A. Spatial autocorrelation in honeybee foraging activity reveals optimal focus scale for predicting agro-environmental scheme efficiency. Ecol Model 2012;225:103-14.

Hensbergen PJ, Van Velzen MJM, Nugroho RA, Donker MH, Van Straalen NM. Metallothionein-bound cadmium in the gut of the insect Orchesella cincta (Collembola) in relation to dietary cadmium exposure. Comp Biochem Physiol C Pharmacol Toxicol Endocrinol 2000;125:17-24.

Jolly S, Bado-Nilles A, Lamand F, Turies C, Chadili E, Porcher JM, et al. Multi-biomarker approach in wild European bullhead, Cottus sp., exposed to agricultural and urban environmental pressures: practical recommendations for experimental design. Chemosphere 2012;87:675-83.

Kim JH, Nam YP, Jeon SM, Han HS, Suk K. Amyloid neurotoxicity is attenuated by metallothionein: dual mechanisms at work. J Neurobiol 2012;121:751-62.

Lagadic L, Caquet T, Amiard JC, Ramade F. Biomarqueurs en Ecotoxicologie, Aspects Fondamentaux. Paris: Masson; 1997 [419 pp.].

Leita L, Muhlbachova G, Cesco R, Barbattini R, Mondini C. Investigation of the use of honeybees and honeybee products to assess heavy metals contamination. Environ Monit Assess 2004;43:1-9.

Leung JYK, Bennett WR, Herbert RP, West AK, Lee PR, Wake H, et al. Metallothionein promotes regenerative axonal sprouting of dorsal root ganglion neurons after physical axotomy. Cell Mol Life Sci 2012;69:809-17.

Lionetto MG, Caricato R, Giordano ME, Pascariello MF, Marinosci L, Schettino T. Integrated use of biomarkers (acetylcholinesterase and antioxidant enzymes activities) in Mytilus galloprovincialis and Mullus barbatus in an Italian coastal marine area. Mar Pollut Bull 2003;46:324-30.

Martín-Díaz ML, Blasco J, Sales D, DelValls TA. Field validation of a battery of biomarkers to assess sediment quality in Spanish ports. Environ Pollut 2008;151:631-40.

Narbonne JF, Aarab N, Clerandeau C, Daubeze M, Narbonne J, Champeau O, et al. Scale of classification based on biochemical markers in mussels: application to pollution monitoring in Mediterranean coasts and temporal trends. Biomarkers 2005;10: 58-71.

Nguyen BK, Saegerman C, Pirard C, Mignon J, Widart J, Tuirionet B, Verheggen FJ, Berkvens D, De Pauw E, Haubruge E. Does Imidacloprid Seed-Treated Maize Have an Impact on Honey Bee Mortality? J Econ Entomol 2009;102:616-23.

Papadopoulos AI, Polemitou I, Laifi P, Yiangou A, Tananaki C. Glutathione S-transferase in the insect Apis mellifera macedonica kinetic characteristics and effect of stress on the expression of GST isoenzymes in the adult worker bee. Comp Biochem Physiol C Toxicol Pharmacol 2004;139:93-7.
Payne JF, Mathieu A, Melvin W, Fancy LL. Acetylcholinesterase, an old biomarker with a new future? Field trials in association with two urban rivers and a paper mill in Newfoundland. Mar Pollut Bull 1996;32:225-31.

Polyzou A, Debras JF, Belzunces LP. Changes in acetylcholinesterase during pupal development of Apis mellifera queen. Arch Insect Biochem Physiol 1997;36:69-84.

Roméo M, Mourgaud Y, Geffard A, Gnassia-Barelli M, Amiard JC, Budzinski H. Multimarker approach in transplanted mussels for evaluating water quality in Charentes, France, coast areas exposed to different anthropogenic conditions. Environ Toxicol 2003;18: 295-305.

Ruttner F. Races of bees. The hive and the honeybee; 1975; 19-38.

Ruttner F. Biogeography and taxonomy of honeybees 1988. Ed. Springer-Verlag: 284 pp.

Saifutdinova Z, Shangaraeva G. Honeybee populations as ecotoxicological indicators. Mutat Res Fundam Mol Mech Mutagen 1997;379:S96.

Sanchez W, Palluel O, Lagadic L, Ait-Aissa S, Porcher JM. Biochemical effects of nonylphenol polyethoxylate adjuvant, Diquat herbicide and their mixture on the threespined stickleback (Gasterosteus aculeatus L.). Mar Environ Res 2006;62:29-33.

Sanchez W, Ait-Aissa S, Palluel O, Ditche JM, Porcher JM. Preliminary investigation of multi-biomarker responses in three-spined stickleback (Gasterosteus aculeatus L.) sampled in contaminated streams. Ecotoxicology 2007;16:279-87.

Sanchez W, Katsiadaki I, Piccini B, Ditche J-M, Porcher J-M. Biomarker responses in wild three-spined stickleback (Gasterosteus aculeatus L.) as a useful tool for freshwater biomonitoring: a multiparametric approach. Environ Int 2008;34:490-8.

Schiedek D, Broeg K, Barsiene J, Lehtonen KK, Gercken J, Pfeifer S, et al. Biomarker responses as indication of contaminant effects in blue mussel (Mytilus edulis) and female eelpout (Zoarces viviparus) from the southwestern Baltic Sea. Mar Pollut Bull 2006;53:387-405

Schneider F. Biométrie des abeilles à la Réunion. Maison Alfort: Thèse vétérinaire; 1989 [91 pp.].

Sohn EJ, Kim DW, Kim MJ, Jeong HJ, Shin MJ, Ahn EH, et al. PEP-1-metallothionein-III protein ameliorates the oxidative stress-induced neuronal cell death and brain ischemic insults. BBA 2012;1820:1647-55.

Stanic B, Andric N, Zoric S, Grubor-Lajsic G, Kovacevic R. Assessing pollution in the Danube River near Novi Sad (Serbia) using several biomarkers in sterlet (Acipenser ruthenus L.). Ecotoxicol Environ Saf 2006;65:395-402.

Stefanidou M, Koutselinis A, Pappas F, Methenitou G. Bee head acetylcholinesterase as an indicator of exposure to organophosphate and carbamate insecticides. Vet Hum Toxicol 1996;38:420-2.

Stone D, Jepson P, Laskowski R. Trends in detoxification enzymes and heavy metal accumulation in ground beetles (Coleoptera: Carabidae) inhabiting a gradient of pollution. Comp Biochem Physiol Part C Toxicol Pharmacol 2002;132:105-12.

Thompson JAJ, Cosson RP. An improved electrochemical method for the quantification of metallothioneins in marine organisms. Mar Environ Res 1984;11:137-52.

Wiest L, Bulete A, Giroud B, Fratta C, Amic S, Lambert O, et al. Multi-residue analysis of 80 environmental contaminants in honeys, honeybees and pollens by one extraction procedure followed by liquid and gas chromatography coupled with mass spectrometric detection. J Chromatogr A 2011;1218:5743-56.

Yu X, Sun R, Yan H, Guo X, Xu B. Characterization of a sigma class glutathione $\mathrm{S}$-transferase gene in the larvae of the honeybee (Apis cerana cerana) on exposure to mercury. Comp Biochem Physiol B Biochem Mol Biol 2012;161:356-64. 